\title{
Essential oils biological activity of the shrub Lippia alba (Verbenaceae)
}

\author{
Mailen Ortega-Cuadros ${ }^{1}$, Ema E. Acosta de Guevara ${ }^{2}$, Ailen D. Molina Castillo ${ }^{3}$, \\ Clara Gutiérrez Castañeda ${ }^{4}$, Glorismar Castro Amarís ${ }^{5} \&$ Adriana P. Tofiño-Rivera ${ }^{6}$ \\ 1. Universidad de Antioquia, Medellin, Colombia; mailen.ortega@udea.edu.co \\ 2. Proyecto Aplicabilidad biotecnológica del aceite esencial de Lippia alba, Grupo de Investigación Gestión Ecológica \\ y Agroindustrial. Universidad Libre Seccional Barranquilla, Km 7 Antigua Vía Puerto Colombia, Colombia; \\ ema.acosta@unilibre.edu.co
}

3. Proyecto Aplicabilidad biotecnológica del aceite esencial de Lippia alba, Grupo de Investigación Gestión Ecológica y Agroindustrial. Universidad Libre Seccional Barranquilla, Km 7 Antigua Vía Puerto Colombia, Colombia; ailend.molinac@unilibre.edu.co

4. Proyecto Aplicabilidad biotecnológica del aceite esencial de Lippia alba, Grupo de Investigación Gestión Ecológica y Agroindustrial. Universidad Libre Seccional Barranquilla, Km 7 Antigua Vía Puerto Colombia, Colombia; clarag.gutierrezc@unilibre.edu.co

5. Universidad Popular del Cesar, Grupo de Investigación Parasitología Agroecología Milenio, Valledupar, Colombia; gcastroa@unicesar.edu.co

6. Corporación Colombiana de Investigación Agropecuaria - AGROSAVIA. Centro de investigación Motilonia. Km 5 vía a Becerril, Agustín Codazzi, Colombia; atofino@agrosavia.co

Received 27-IX-2019. Corrected 02-XII-2019. Accepted 30-I-2020.

\begin{abstract}
Introduction: Lippia alba is an aromatic species belonging to the Verbenaceae family. Its essential oils have been used in different industries, because of its biological properties. Objective: Identify the perspectives of the biotechnological applications of Lippia alba essential oils. Methodology: A scoping review was conducted on the biological activity of Lippia alba essential oils registered until October, 2018 in EBSCO, Embase, Pubmed, Scopus, SciELO, and Lilacs databases. Results: Chemotypes I and III have been reported for different biological activities from the evaluations performed on microorganisms, fish, arthropods, small mammals, and cell lines; fundamentally associated with antibacterial, antifungal, cytotoxic, antioxidant, and sedative effects, among others. Records focused mainly on the health, fishing industry, and agrifood sectors. Conclusion: Studies on the effect of essential oil are promising, but do not reflect a continuity of the research toward prototypes or finished commercial products. Research groups must unify evaluation methodologies and include in all studies the relationship between phytochemical and biological activity for the meta-analyses to be possible. Likewise, they must join efforts through the National System for Agricultural Innovation (SNIA, for the term in Spanish) to generate finished products that impact upon society and facilitate progress in the country's bio-economy.
\end{abstract}

Key words: Lippia alba, essential oils, chemotypes, aromatic plants, health protection, food industry, agrifood sector.

Ortega-Cuadros, M., Acosta de Guevara, E.E., Molina Castillo, A.D., Gutiérrez Castañeda, C., Castro Amarís, G., \& Tofiño-Rivera A.P. (2020). Essential oils biological activity of the Lippia alba (Verbenaceae) shrub. Revista de Biología Tropical, 68(1), 344-359.

\section{SUPPLEMENTARY MATERIAL}

Acronym definition: MIC: minimum inhibitory concentration; MBC: minimum bactericide concentration; LD50: lethal dosage 50; LD or LC: lethal dosage or lethal concentration; IC50: minimum inhibition concentration 50; CC50: cytotoxic concentration 50; EC50: effective concentration 50; RP50: repellency 50; RP: repellency percentage; CHO: Chinese hamster ovary cells; VERO: African green monkey kidney; A549: human lung carcinoma cell line; THP-1: human leukemic monocyte cells; Jurkat: T-cell lymphocytes with acute lymphoid leukemia; HepG2: hepatocellular liver cells; HeLa: human cervical epithelial carcinoma. 
Organic products are broadly used by the global population for essential healthcare (Plantlife International, 2004; Grand View Research, 2018). In 2017 the market of personal-care products reached \$12.19-billion, and further growth is foreseen (Grand view research, 2018). Medicinal and Aromatic Plants (MAPs) are a natural source of chemical substances that provide diverse biological properties (Bouyahya, Guaouguaou, Dakka, \& Bakri, 2017). That is why countries several countries (i.e. the United States, Brazil, India, Colombia, and Cuba) support scientific research that let the discussion of the biological properties of MAPs and support better uses focused on bioprospection (Tofiño-Rivera, Ortega-Cuadros, Melo-Ríos, \& Mier-Giraldo, 2017).

Colombia has an outstanding floristic wealth, among which are included several promising MAPs of interest for science, such as Lippia alba (Mill.) N.E. Br, an aromatic species belonging to the Verbenaceae family, whose essential oils have been used in the cosmetic, food, and biomedical industries (Tofiño-Rivera et al., 2017; Linde, Colauto, Albertó, \& Gazim, 2016) due to its biological properties. However, these properties are derived from the plant's phytochemical composition. The presence and concentration of secondary metabolites is influenced by agro-economic management applied to the production of biomass, the phenological cycle of the material harvested, edaphoclimatic conditions, extraction method of the essential oil (Olivero-Verbel, González-Cervera, GüetteFernandez, Jaramillo-Colorado, \& Stashenko, 2010; Linde et al., 2016), and the evaluation technique employed in some cases (Ramírez \& Castaño, 2009). This scoping review was conducted to identify the perspectives of the biotechnological application of essential oils (EO) of Lippia alba (Mill.) N.E. Br.

A scoping review (Armstrong, Hall, Doyle, \& Waters, 2011) was carried out on the scientific literature that describes the biological activity of $L$. alba EO. Likewise, a search equation was elaborated by using the terms "Lippia alba and essential oil", which was used to access published articles deposited in
EBSCO, Embase, Pubmed, Scopus, SciELO, and Lilacs, since the beginning of time for each database, until October $8^{\text {th }}, 2018$. The registries recovered were filtered to eliminate duplicates using Zotero. Inclusion and exclusion criteria were applied. A select group of documents was obtained to which a detailed analysis was applied (Fig. 1). The variables of interest (year, country, author, title, institution, EO extraction technique, biological activity evaluated, evaluation method, object of study, and result obtained) were extracted and compiled in a database using Microsoft Excel 2016. IBM SPSS 23.0 was used to conduct the statistical analyses. Application of the research protocol was conducted independently by two researchers to guarantee reproducibility of the work, and the discrepancies observed were solved through a third-party concept.

Bibliometric analysis: The search recovered 706 registries, from which 115 documents were analyzed (Fig. 1). It was identified that L. alba EO and their respective biological activity have been topics of interest in the scientific community since 1990 . The publication of scientific articles has not been continuous. Countries with higher rate of published articles related with the subject are Brazil with 70 (60.5\%), Colombia with $29(25.2 \%)$, and India with $7(6.2 \%)$. The institutions that have led these investigations are Universidad Federal de Santa María with 18 (15.6\% publications), Universidad Industrial de Santander with 8 (6.9\% publications), Universidad de Cartagena with 6 (5.2\% publications), Universidade Regional do Cariri with 6 (5.2\% publications), and Universidade Federal da Bahía with 3 (2.6\% publications).

Biological activity of $L$. alba essential oils: This exploratory review evidences the interest by the scientific community in progressing on the knowledge of the safe use of the derivates of these aromatic species. $L$. alba essential oils are antigenotoxic (Vera, Olivero, Jaramillo, \& Stashenko, 2010; López, Stashenko, \& Fuentes, 2011; Neira, Mantilla, 


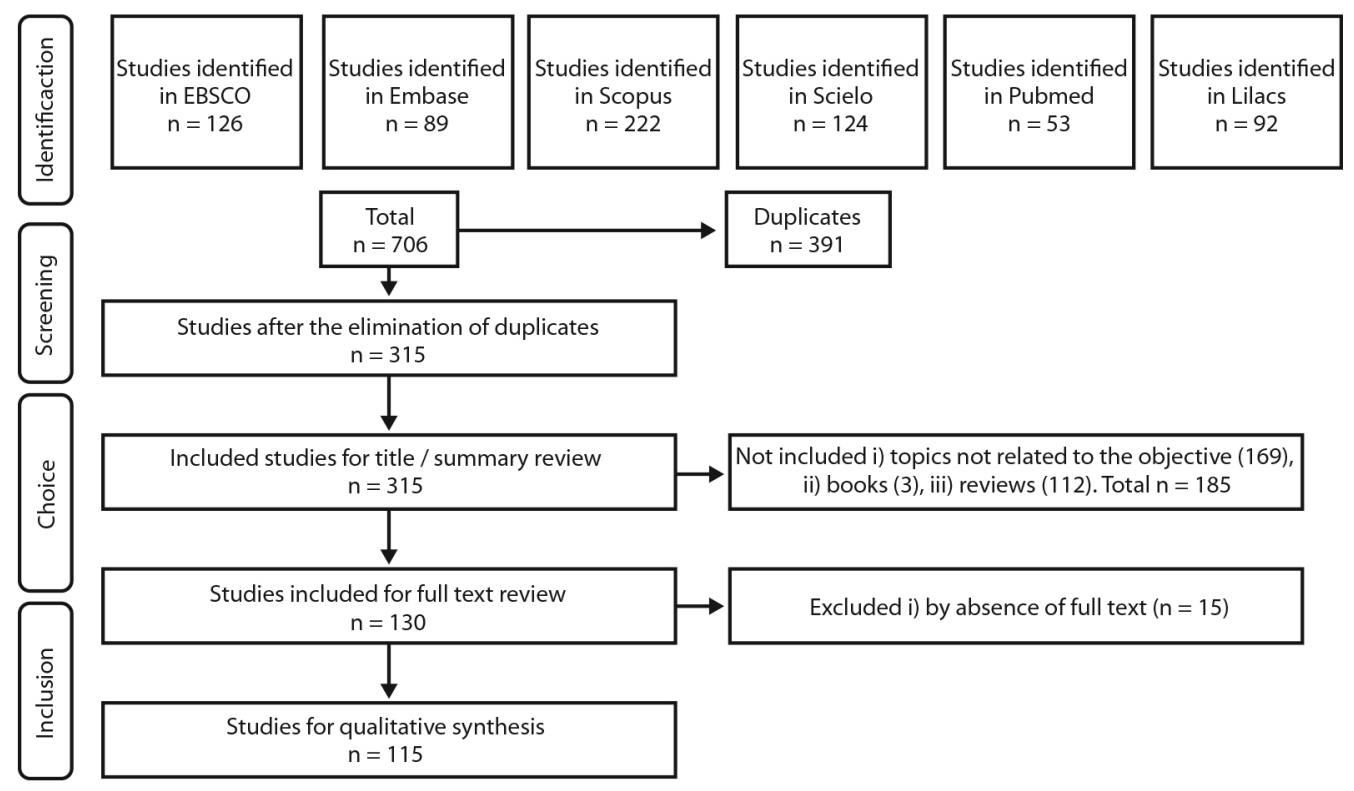

Fig. 1. Summary of the protocol of the exploratory systematic review applied and the respective results. Source: elaborated by the authors.

Stashenko, \& Escobar, 2018), but are toxic for Artemia franciscana, on which DL 6.17$24.87 \mu \mathrm{g} / \mathrm{ml}$ were presented (Olivero-Verbel, Güette-Fernandez, \& Stashenko, 2009) and DL 50.4-21.05 $\mu \mathrm{g} / \mathrm{ml}$ (Olivero-Verbel, GonzálezCervera et al., 2010). In mice, oral administration with dosages of $2000 \mathrm{mg} / \mathrm{kg}$ is lethal; $900-1500 \mathrm{mg} / \mathrm{kg}$ is life compatible but causes signs and symptoms of neurological damage and moderate to severe motor impairment as ataxia, lethargy, salivation, and transitory convulsions (Aular, Villamizar, Pérez, \& Pérez, 2016). Intraperitoneal administration of dosages $\geq 1500 \mathrm{mg} / \mathrm{kg}$ causes neurological damage, and dosages of $1000 \mathrm{mg} / \mathrm{kg}$ cause slight hepatic damage (Olivero-Verbel, GuerreroCastilla, \& Stashenko 2010). On CHO cells, the oils did not inhibit cell proliferation at concentrations of $0.01-1 \mu \mathrm{g} / \mathrm{ml}$ (Tofiño-Rivera et al., 2016), with reports for VERO CC50 cells of 25.3-200 $\mu \mathrm{g} / \mathrm{ml}$ (Meneses, Ocazionez, Martínez, \& Stashenko, 2009; Escobar, Leal, Herrera, Martinez, \& Stashenko, 2010; Moreno, Leal, Stashenko, \& García, 2018; Zapata, Betancur-Galvis, Duran, \& Stashenko, 2013),
A549 CI50 $47.80 \mu \mathrm{g} / \mathrm{ml}$ (Gomide et al., 2013), THP-1 CC50 16.8-43.17 $\mu \mathrm{g} / \mathrm{ml}$ (Escobar et al., 2010; Neira et al., 2018), Jurkat CI50 16.6-31.6 $\mu \mathrm{g} / \mathrm{ml}$, HepG2 CI50 21.5-200 $\mu \mathrm{g} / \mathrm{ml}$ (Zapata et al., 2013), and HeLa CI50 5-80.5 $\mu \mathrm{g} / \mathrm{ml}$ (Agudelo-Gómez, Gómez, Durán, Stashenko, \& Betancur-Galvis, 2010; Zapata et al., 2013).

L. alba is a species cultivated in different tropical, subtropical, and temperate zones throughout the world (Linde et al., 2016); its essential oils are promising due to their chemical diversity (Linde et al., 2016; Tofiño-Rivera et al., 2017). However, this chemical composition is sensibly dependent on the geographic location and the phenology of the plant material harvested (Durán, Monsalve, Martínez, \& Stashenko, 2007), which has categorized $L$. alba in seven chemotypes (Table 1; Linde et al., 2016). Essential oils from chemotypes I and III plants present antispasmodic (Viana, Vale, Silva, \& Matos, 2000; Blanco et al., 2013; Sousa et al., 2015; Silva et al., 2018; Carvalho et al., 2018), anticonvulsive (Fauth, Campos, Silveira, \& Rao, 2002; Maynard et al., 2011), anxiolytic (Hatano, Torricelli, Giassi, Coslope, 
TABLE 1

L. alba chemotypes

\begin{tabular}{cl} 
Chemotype & \multicolumn{1}{c}{ Description of the essential oil composition (principal constituent components) } \\
I & Citral, linalool, $\beta$-Caryophylene (four subtypes within this chemotype) \\
II & Tagetenone \\
III & Limonene in large amounts and a variable amount of carvone or monoterpenic ketones instead of carvone \\
IV & Myrcene \\
V & $\gamma$-terpinen \\
VI & Canfora-1,8-cineole \\
VII & Estragole \\
\hline
\end{tabular}

Source: elaborated by the authors.

\& Viana, 2012; Junior et al., 2018), and antiinflammatory effects (Sepúlveda-Arias, Veloza, Escobar, Orozco, \& Lopera, 2013). On contact with the skin, they are not irritating nor alter the histopathology (Neira et al., 2018), and are sleep enhancers (Fauth et al., 2002), anesthetic, and sedative (Salbego et al., 2017a). They also have antioxidant activity, although in this property the collection site is quite determining, given that chemotype I was a good antioxidant, while other chemotype III specimens had moderate and absent effect (Stashenko, Jaramillo, \& Martínez, 2004; Olivero-Verbel, GonzálezCervera et al., 2010).

Insecticide activity has been reported for chemotypes I and III; it was reported on Rhipicephalus microplus, RP50 0.47-5.07 $\mathrm{mg} / \mathrm{cm}^{2}$ (Lima et al., 2016) and CL50 8.8-27 mg/ml (Peixoto et al., 2015b; Chagas et al., 2016), on Tribolium castaneum, RP 34-96 \% in concentrations of $0.00002-0.2 \mu \mathrm{L} / \mathrm{cm}^{2}$ (CaballeroGallardo, Olivero-Verbel, \& Stashenko, 2011) and CL50 19.7-107.8 $\mu \mathrm{L} / \mathrm{ml}$, and on Sitophilus zeamais, CL50 15.2-70.8 $\mu \mathrm{L} / \mathrm{ml}$ (Peixoto et al., 2015a). Chemotype III presents dissuasion $>80 \%$ in oviposition of Aedes aegypti at concentrations of 0.005-0.2 $\mu \mathrm{g} / \mathrm{ml}$ (Castillo, Stashenko, \& Duque, 2017), and it also has larvicidal activity at variable concentrations: Vera et al. (2014) reported CI50 0.042-0.044 $\mu \mathrm{g} / \mathrm{ml}$ and IC95 0.089-0.099 $\mu \mathrm{g} / \mathrm{ml}$; Muñoz, Stashenko and Ocampo (2014), CL50 $0.11 \mu \mathrm{g} /$ $\mathrm{ml}$ and CL99 $0.211 \mu \mathrm{g} / \mathrm{ml}$; Ríos, Stashenko and Duque (2017), CL50 63.61 - $72.34 \mu \mathrm{g} /$ $\mathrm{ml}$ CL95 98.91-110.84 $\mu \mathrm{g} / \mathrm{ml}$; and Aldana and Cruz (2017), CL50 of $84-367 \mu \mathrm{g} / \mathrm{ml}$ and CL95 of $118-506 \mu \mathrm{g} / \mathrm{ml}$.

Antiviral activity was not evidenced for chemotype I (Agudelo-Gómez et al., 2010), but chemotype III had preventive effect on cells infected with dengue virus (serotypes DENV-1, DENV-2, DENV-3, DENV-4) (Ocazionez, Meneses, Torres, \& Stashenko, 2010). The concentration of $11.1 \mu \mathrm{g} / \mathrm{ml}$ reduced the viral titers of the agent causing yellow fever (VFA) (Meneses et al., 2009), and concentrations of 125 and $250 \mu \mathrm{g} / \mathrm{ml}$, at 24 and $48 \mathrm{~h}$, respectively, reduced $10^{1.5} \log$ units the viral load of an HSV-1 isolate sensitive to Acyclovir (Agudelo-Gómez et al., 2010).

The amoebicidal activity of chemotype III was reported on Acanthamoeba polyphaga trophozoites with IC50 $31.79 \mu \mathrm{g} / \mathrm{ml}$ (Santos et al., 2016b); leishmanicide activity on Leishmania braziliensis (promastigote CE50 8.88 $\mu \mathrm{g} / \mathrm{ml}$ and amastigote CE50 $9.19 \mu \mathrm{g} / \mathrm{ml}$ ) and Leishmania chagasi (promastigote CI50 18.9 - $100 \mu \mathrm{g} / \mathrm{ml}$ ) (Neira et al., 2018; Escobar et al., 2010). The trypanocidal effect is variable because for Trypanosoma cruzi, Moreno et al. (2018) determined that chemotype I had IC50 14.22 and $74 \mu \mathrm{g} / \mathrm{ml}$ on epimastigote, trypomastigote, and amastigote, while chemotype III had IC50 88.45 and $>150 \mu \mathrm{g} / \mathrm{ml}$ for the same parasite forms. For chemotype I, Escobar et al., (2010) obtained bio-activity on epimastigotes IC50 5.5-8.8 $\mu \mathrm{g} / \mathrm{ml}$, and amastigote IC50 $12.2-17.47 \mu \mathrm{g} / \mathrm{ml}$; and for chemotype III, 
epimastigote IC50 $8.8 \mu \mathrm{g} / \mathrm{ml}$ and amastigote IC50 $17.47 \mu \mathrm{g} / \mathrm{ml}$. Additionally, Baldissera, Souza, Mourão, Silva, and Monteiro (2017) reported that under in-vitro conditions, concentrations of $0.5,1$, and $2 \%$ of chemotype I had direct correlation with the efficacy in controlling Trypanosoma evansi, but under in-vivo conditions in mice; treatment with $1.5 \mathrm{ml} \mathrm{Kg}^{-1}$ did not show curative efficacy. Nematicidal activity of chemotypes I and III was reported on Meloidogyne incognita at concentrations from $0.1-2.5 \mathrm{ml} / \mathrm{L}$, which had mean mortality percentages from 22 to $100 \%$, in dependent dosage; and diminished eclosion rate from 47 to $9 \%$ (Moreira, Santos, \& Innecco, 2009).

Antimicrobial and antifungal activity has been reported on periodontal-pathogenic microorganisms (Juiz et al., 2015; Bersan et al., 2014), cariogenic organisms (Bersan et al., 2014), enterobacteria (Pino, Ortega, Rosado, Rodríguez, \& Baluja, 1996; Machado, Nogueira, Pereira, Sousa, \& Batista, 2014), dermatophytes (Costa et al., 2014; Tangarife-Castaño et al., 2012), phytopathogens (Mena-Rodríguez, Ortega-Cuadros, Merini, Melo-Ríos, \& Tofiño-Rivera, 2018; Anaruma et al., 2010), sulfate reductase (Souza et al., 2017a), important pathogens in aquiculture (Souza et al., 2017b; Majolo, Rocha, Chagas, Chaves, \& Bizzo, 2017; Sutili et al., 2015), Candida albicans (Mesa-Arango et al., 2010; Santos et al., 2016a; Mesa-Arango et al., 2009), aspergillosis (Mesa-Arango et al., 2010; Glamočlija, Soković, Tešević, Linde, \& Colauto, 2011; Mesa-Arango, et al., 2009), Cryptococcosis (Santos et al., 2016a); gastrointestinal, cutaneous, and nosocomial infections (Pino et al., 1996; Machado et al., 2014; Porfírio et al., 2017); under the MIC interval between 4.0-9 $370 \mu \mathrm{g} / \mathrm{ml}$ and MBC 6.5-2 $500 \mu \mathrm{g} / \mathrm{ml}$ for bacteria (Table 2), and MIC 31.25-2 000 and $\mathrm{MBC} /$ MFC 500-1 $250 \mu \mathrm{g} / \mathrm{ml}$ for fungus (Table 3).

Final considerations: $L$. alba is promising plant in Latin America (Tofiño-Rivera et al., 2017), which is included in the Colombian Vademecum of Medicinal Plants (Ministry of Health and Social Protection [MinSalud],
2008), and is approved for over-the-counter sale as antiseptic for external use and adjuvant in the treatment of anxiety of nervous origin in humans (INVIMA, 2018). According to the records found, L. alba essential oils are bioinputs of interest, given their possibility of bioprospection. In biomedical sciences, research has provided effective tools to solve problems related with amoebic infections (Santos et al., 2016b), herpetic infections (Agudelo-Gómez et al., 2010), tropical diseases e.g. like dengue (Ocazionez et al., 2010), leishmaniasis (Escobar et al., 2010; Neira et al., 2018), trypanosomiasis (Escobar et al., 2010; Baldissera et al. 2017; Moreno et al., 2018), and yellow fever (Meneses et al., 2009), control of vectors, like Aedes aegypti (Vera et al., 2014; Castillo et al., 2017; Ríos et al., 2017; Aldana \& Cruz, 2017), mycosis (Mesa-Arango et al., 2010; Santos et al., 2016a; Glamočlija et al., 2011), in-hospital diseases (Santos et al., 2016a; Pino et al., 1996; Machado et al., 2014), and diseases related with the oral cavity (Juiz et al., 2015; Bersan et al., 2014).

In addition, the agroindustrial sector has focused on the use of L. Alba EO to control efficiently parasites that affect vegetable production (Moreira et al., 2009), improve grain conservation (Caballero-Gallardo et al., 2011; Peixoto et al., 2015a; Shukla, Kumar, Singh, \& Dubey, 2009), improve the quality of products derived from livestock (Peixoto et al., 2015b; Lima et al., 2016; Chagas et al., 2016), as well as diminish damage during transport of ornamental aquatic species, like Hippocampus reidi (Cunha et al., 2011); anesthetics for model organisms, like Hypsiboas geographicus (Salbego et al., 2017a); sedatives, anesthetics, and preservatives in hedgehogs (Simões et al., 2017) and shrimp (Parodi et al., 2012), and fish of economic importance (Sena et al., 2016; Hohlenwerger et al., 2017; Cunha et al., 2010).

In aquiculture, for $L$. alba essential oils, chemotype I has reported promising results, given their sedative effect on Rhamdia quelen (20-40 $\mu \mathrm{L} / \mathrm{L})$ (Salbego et al., 2017b; Veeck et al., 2018); anesthetic effect on Litopenaeus vannamei (> $30 \mu \mathrm{L} / \mathrm{L})$ (Parodi et al., 2012), 
TABLE 2

Minimum inhibitory concentration (MIC) and minimum bactericide concentration (MBC) of chemotypes I and III essential oils on bacterial species

\begin{tabular}{|c|c|c|c|c|c|}
\hline Microorganism & Strain/isolate & $\mathrm{MIC}(\mu \mathrm{g} / \mathrm{ml})$ & $\mathrm{MBC}(\mu \mathrm{g} / \mathrm{ml})$ & Chemotype & Reference \\
\hline Aeromonas spp. & $\begin{array}{l}\text { Isolates, } \\
\text { ATCC } 7966\end{array}$ & $2862-5.000$ & $781.3-6.000$ & I & $\begin{array}{c}\text { (Sutili et al., 2015; } \\
\text { Majolo et al., 2017; } \\
\text { Souza, Costa et al., 2017) }\end{array}$ \\
\hline $\begin{array}{l}\text { Aggregatibacter } \\
\text { actinomycetemcomitans }\end{array}$ & ATCC 43717 & $>3200$ & $>3200$ & III & (Juiz et al., 2015) \\
\hline Bacillus subtilis & ATCC 7001 & 630 & 1.250 & III & (Pino et al., 1996) \\
\hline Bacteroides fragilis & ATCC 25285 & $400-1600$ & $400-1600$ & III & (Juiz et al., 2015) \\
\hline Desulfovibrio alaskensis & NCIMB 13491 & $78-2500$ & & I & (Souza, Goulart et al., 2017) \\
\hline Enterobacter aerogenes & ATCC 13088 & 2500 & 2500 & III & (Pino et al., 1996) \\
\hline Enterococcus faecalis & ATCC 19433 & $630-4000$ & 1250 & I and III & $\begin{array}{c}\text { (Pino et al., 1996; } \\
\text { Santos et al., 2016a) }\end{array}$ \\
\hline Escherichia coli & $\begin{array}{l}\text { ATCC 25922, } \\
\text { 201389, 10536, } \\
\text { Isolates }\end{array}$ & $400-4000$ & $2500-1170$ & I and III & $\begin{array}{c}\text { (Pino et al., 1996; Duarte et al., } \\
\text { 2007; Machado et al., 2014; } \\
\text { Santos et al., 2016a) }\end{array}$ \\
\hline Fusobacterium nucleatum & ATCC 25586 & 125 & 125 & I & (Bersan et al., 2014) \\
\hline Klebsiella pneumoniae & ATCC 13883 & 2500 & 2500 & III & (Pino et al., 1996) \\
\hline Listeria innocua & ATCC 19115 & $580-1330$ & $1330-1170$ & I & (Machado et al., 2014) \\
\hline Listeria monocytogenes & ATCC 33090 & $580-1330$ & $580-1330$ & I & (Machado et al., 2014) \\
\hline Porphyromonas gingivalis & ATCC 33277 & $6.5-250$ & $6.5-250$ & I and III & $\begin{array}{c}\text { (Bersan et al., 2014; Juiz et } \\
\text { al., 2015) }\end{array}$ \\
\hline Pseudomonas aeruginosa & ATCC 9027 & $5340-9370$ & $5340-9370$ & I & (Machado et al., 2014) \\
\hline Salmonella choleraesuis & ATCC 10708 & $5340-9370$ & $5340-9370$ & I & (Machado et al., 2014) \\
\hline Serratia marcescens & $\begin{array}{l}\text { ATCC } 8100 \\
\text { MBCAI } 469\end{array}$ & $630-4000$ & 1250 & I and III & $\begin{array}{l}\text { (Pino et al., 1996; } \\
\text { Santos et al., 2016a) }\end{array}$ \\
\hline Staphylococcus aureus & $\begin{array}{l}\text { ATCC } 6538, \\
\text { ATCC } 25923\end{array}$ & $290-1000$ & $290-2000$ & I and III & $\begin{array}{l}\text { (Pino et al., 1996; Machado et } \\
\text { al., 2014; Porfírio et al., 2017) }\end{array}$ \\
\hline Streptococcus mitis & ATCC 903 & 250 & - & I & (Bersan et al., 2014) \\
\hline Streptococcus sanguis & ATCC 10556 & 250 & 100000 & I & (Bersan et al., 2014) \\
\hline
\end{tabular}

Source: elaborated by the authors.

Colossoma macropomum $(62,5-375 \mu \mathrm{L} / \mathrm{L})$ (Batista et al., 2018), Echinometra lucunter (150 $\mu \mathrm{L} / \mathrm{L})$ (Simões et al., 2017), Rhamdia quelen (20 and 150-450 $\mu \mathrm{L} / \mathrm{L}$ ) (Cunha et al., 2010; Toni et al., 2014; Veit et al., 2017; Salbego et al., 2017b), Argyrosomus regius (200 $\mu \mathrm{L} / \mathrm{L}$ ) (Cárdenas et al., 2016), Serrasalmus rombeus $(50-200 \mu \mathrm{L} / \mathrm{L})$ (Almeida, Heinzmann, Val, \& Baldisserotto, 2018), Sparus aurata (100-300 $\mu \mathrm{L} / \mathrm{L}$ ) (Toni et al., 2015); and reduce stress in Rhamdia quelen $(10-40 \mu \mathrm{L} / \mathrm{L})$ (Azambuja et al., 2011; Veeck et al., 2013), Oreochromis niloticus $(20 \mu \mathrm{L} / \mathrm{L})$ (Hohlenwerger et al., 2017), Litopenaeus vannamei (> $30 \mu \mathrm{L} / \mathrm{L}$ ) (Parodi et al., 2012), Echinometra lucunter (150 $\mu \mathrm{L} / \mathrm{L})$ (Simões et al., 2017), and tambacu hybrids (Piaractus mesopotamicus $\times$ Colossoma macropomum $)(200 \mu \mathrm{L} / \mathrm{L})$ (Sena et al., 2016).

Chemotype I EO can be used to enhance aquaculture techniques because they maintain the freshness of fish stored in ice (Veeck et al., 2018), do not modify the organoleptic characteristics (Cunha et al., 2010; Toni et al., 2014; Hohlenwerger et al., 2017), or affect fish quality (Sena et al., 2016). However, further studies are needed, given that Veeck et al. (2018) reported that concentrations from 30-40 $\mu \mathrm{l} / \mathrm{L}$ do not represent antimicrobial activity against mesophiles and psychrophiles, and Veit 
TABLE 3

Minimum inhibitory concentration (MIC) and minimum fungicide concentration (MFC), of chemotypes I and III essential oils on fungal species

\begin{tabular}{|c|c|c|c|c|c|}
\hline Microorganism & Strain/isolate & $\mathrm{MIC}(\mu \mathrm{g} / \mathrm{ml})$ & $\begin{array}{c}\text { MFC } \\
(\mu \mathrm{g} / \mathrm{ml})\end{array}$ & Chemotype & Reference \\
\hline Aspergillus flavus & ATCC 204304 & $180-1600$ & - & I and III & $\begin{array}{l}\text { (Mesa-Arango et al., 2009; } \\
\text { Mesa-Arango et al., 2010) }\end{array}$ \\
\hline Aspergillus fumigatus & ATCC 204305, ATCC9142 & $35-570$ & 1250 & I and III & $\begin{array}{l}\text { (Mesa-Arango et al., 2009; } \\
\text { Mesa-Arango et al., 2010; } \\
\text { Glamočlija et al., 2011) }\end{array}$ \\
\hline Aspergillus niger & ATCC6275 & 600 & 600 & I & (Glamočlija et al., 2011) \\
\hline Aspergillus ochraceus & ATCC12066 & 300 & 600 & I & (Glamočlija et al., 2011) \\
\hline Aspergillus versicolor & ATCC11730 & 300 & 600 & I & (Glamočlija et al., 2011) \\
\hline Candida albicans & $\begin{array}{l}\text { MBCAI 560, ATCC 10231, } \\
\text { CBS } 562\end{array}$ & $250-2000$ & 500 & I & $\begin{array}{l}\text { (Duarte, Figueira, Sartoratto, } \\
\text { Rehder, \& Delarmelina, 2005; } \\
\text { Bersan et al., 2014; Santos et } \\
\text { al., 2016a) }\end{array}$ \\
\hline Candida dubliniensis & ATCC 7978 & 500 & - & I & (Santos et al., 2016a) \\
\hline Candida glabrata & ATCC 90030 & 2000 & - & I & (Santos, 2016a) \\
\hline Candida krusei & ATCC 6258 , clinical isolate & $140-2000$ & - & I and III & $\begin{array}{l}\text { (Mesa-Arango et al., 2009; } \\
\text { Mesa-Arango et al., 2010; } \\
\text { Santos et al., 2016a) }\end{array}$ \\
\hline Candida parapsilosis & ATCC 22019, clinical isolate & $280-2000$ & - & I and III & $\begin{array}{l}\text { (Mesa-Arango et al., 2009; } \\
\text { Mesa-Arango et al., 2010; } \\
\text { Santos, 2016a) }\end{array}$ \\
\hline Candida tropicalis & ATCC 13803 & 2000 & - & I & (Santos et al., 2016a) \\
\hline Colletotrichum gloeosporioides & Isolates & $300-900$ & - & I & $\begin{array}{l}\text { (Anaruma et al., 2010; Mena- } \\
\text { Rodríguez et al., 2018) }\end{array}$ \\
\hline Cryptococcus gattii & $\begin{array}{l}\text { ATCC MYA-4560, MYA-4563, } \\
\text { ATCC } 208821\end{array}$ & $1000-2000$ & - & I & (Santos et al., 2016a) \\
\hline Cryptococcus grubii & ATCC 208821 & 1000 & - & I & (Santos et al., 2016a) \\
\hline Cryptococcus neoformans & ATCC MYA-4560 & 1000 & - & I & (Santos et al., 2016a) \\
\hline Fusarium oxysporum & ATCC 48112 & $>500$ & - & I and III & (Tangarife-Castaño et al., 2012) \\
\hline Macrophomina phaseolina & Isolates & $800-1200$ & - & I & (Mena-Rodríguez et al., 2018) \\
\hline Microsporum gypseum & Human isolates & 156 & - & I & (Costa et al., 2014) \\
\hline Penicillium funiculosum & ATCC10509 & 1250 & 1250 & I & (Glamočlija et al., 2011) \\
\hline Penicillium ochrochloron & ATCC9112 & 600 & 1250 & I & (Glamočlija et al., 2011) \\
\hline Phytophthora capsici & Isolates & $50-150$ & - & I & (Mena-Rodríguez et al., 2018) \\
\hline Saccharomyces cerevisiae & ATCC MYA-4567 & 2000 & - & I & (Santos et al., 2016a) \\
\hline Trichoderma viride & ATCC5061 & 600 & 1250 & I & (Glamočlija et al., 2011) \\
\hline Trichophyton mentagrophytes & ATCC 24198 & $125-500$ & - & I and III & (Tangarife-Castaño et al., 2012) \\
\hline Trichophyton rubrum & ATCC 28188 , human isolates & $31.25-354.98$ & - & I and III & $\begin{array}{l}\text { (Tangarife-Castaño et al., 2012; } \\
\text { Costa et al., 2014) }\end{array}$ \\
\hline
\end{tabular}

Source: elaborated by the authors.

et al. (2017) obtained that $375 \mathrm{ml} / \mathrm{L}$ do not prevent physico-chemical changes produced by the electric stunning or hypothermia in fillets of Rhamdia quelen during frozen storage. Some important recommendations have been considered: 1) to transport live fish, 15 $\mu \mathrm{L} / \mathrm{L}$ of essential oil for Argyrosomus regius, or $100-300 \mu \mathrm{L} / \mathrm{L}$ for Sparus aurata, or 62.5$375 \mu \mathrm{L} / \mathrm{L}$ for Colossoma macropomum are not recommended because these do not prevent the 
response to stress (Toni et al., 2015; Cárdenas et al., 2016; Batista et al., 2018); 2) prior sedation is not recommended with $200 \mu \mathrm{L} / \mathrm{L}$ during three minutes with $L$. alba E Oto reduce initial agitation, nor is treatment recommended with 30-40 $\mu \mathrm{L} / \mathrm{L}$ EO for transport because it does not avoid oxidative stress in liver (Salbego et al., 2014); for Argyrosomus regius, $15 \mu \mathrm{L} / \mathrm{L}$ is not recommended to transport live fish, given that it does not inhibit stress (Cárdenas et al., 2016); 3) concentrations of 1600 and $3200 \mu \mathrm{L} / \mathrm{L}$ of chemotype III oils are effective against Anacanthorus spathulatus, Notozothecium janauachensis, and Mymarothecium boegeri, natural parasites of Colossoma macropomum; but these dosages are toxic to fish gills, therefore, there is a need to propose strategies to take advantage of the antihelmintic effect of these products without affecting the host organism, using cutting-edge biotechnological techniques, like nanotechnology (Soares et al., 2016).

Chemotypes I and III seem to be the most common. Chemotype I has more reports on the biological effect; however, it must be considered that the cell and molecular characteristics of each microorganism or organism also interfere with the EO spectrum, given that on Tribolium castaneum and Sitophilus zeamais parasites, chemotype III was more effective than chemotype I (Peixoton et al., 2015a), but on Candida krusei and Aspergillus fumigatus, chemotype I was more effective (Mesa-Arango, et al., 2009). Additionally, chemotype I had anesthetic effect on Hypsiboas geographicus (Salbego et al., 2017a), but not on Neohelice granulata (Souza et al., 2018), and chemotype III was anti-inflammatory in the RAW 264.7 murine cell line (Sepúlveda-Arias et al., 2013), but this effect was not registered on Oreochromis niloticus (Rodrigues-Soares et al., 2018).

One of the critical variables associated with energizing an industry through $L$. alba EO corresponds to the phytochemical characterization of the plant material from which it is extracted, given that the availability of raw material with standardized conditions constitutes a critical point for the bio-industry
(BIOinTropic, Universidad EAFIT, \& Silo, 2018). We can highlight the lack of a comprehensive productive model for the agroindustrial use of $L$. alba because only specific studies are identified on a single management practice and for a specific area of the country (Zambrano, Buitrago, Durán, Sánchez, \& Bonilla, 2013).

Regarding this work, it was found that 18.3 $\%$ of the articles did not relate the biological activity of the EO with its composition, given that no indication is provided of the chemotype or majority components. In this sense, under a general vision of the registries recovered, exploratory or preliminary works were observed without the continuity of the evaluation, according to the Colombian technical standards and norms by the WHO to advance in the formulation of bio-products (Decree 677, 1995; Decree 2510, 2003; WorWHO, 2004; ICONTEC, 2011), which is reflected in the lack of patents registered or pending, although research groups exist in Colombia that include L. alba as study model (Tofiño-Rivera et al., 2017). A vector and confluent effort as a country is needed here through strategies defined within the National Agricultural Innovation System (SNIA, for the term in Spanish) to encourage development based on bio-economy and, thus, take advantage of the diversity of L. alba chemotypes registered throughout the country -citral in Bolívar and Cesar, limonene in Arauca, and carvone in Cundinamarca, Tolima, Boyacá, Valle del Cauca, Santander, Antioquia, Quindío, and Cesar (Durán et al., 2007; Mesa-Arango et al., 2009; Olivero-Verbel, Guerrero-Castilla et al., 2010; Tofiño-Rivera et al., 2016)-, considering the specific uses referred by the scientific literature and which have been systematized in this document.

Unlike synthetic substances (Célis, 2018) and other natural standardized substances in which the concentration used over the same or different organisms will permit a meta-analysis for a finer verification of the biological effect of the substance in context (Valero et al., 2011), this possibility would not be rigorous in the case of the set of documents recovered in this research on the biological activity of $L$. alba 
EO because although many of the investigations refer to the chemotype or the majority component, the same concentration of EO, or the same chemotype, may have large variations in the concentrations of its majority or minority components. This variation is dependent on the equation that explains the phenotypic expression of an attribute $F=G+A+G X A$ : chemotype -genetics G-, bioclimatic offer of the plantation -A-, and the genotype $\mathrm{x}$ environment interaction -GXA-, which are conditioners of the plant's physiological response over the secondary metabolism, upon the bioclimatic offer, agro-economic management, and harvest time (Palacio-López \& Rodríguez-López, 2008). In addition to this heterogeneity exhibited by the raw material, the extraction method also affects the final composition of the EO, which hinders the possibility for a meta-analysis for the bioactivity of $L$. alba from a set of studies with high variability in the concentrations of the bioactive components of the EO (Durán et al., 2007; García-Perdomo, 2015; Barrientos, Reina, \& Chacón, 2012; Delgado, Sánchez, \& Bonilla, 2016). It would, then, be important to have a set of studies with detailed phyto-chemistry of the EO and which use the individual standardized bioactive components as controls (Ortega-Cuadros, Tofiño-Rivera, Merini, \& Martinez-Pabón, 2018). Other exploratory revision works have registered the variable biological activity of the $L$. alba EO, specifically in the results of microbial control, dependent on the extraction technique used and the quality of biomass harvested. This work also highlighted high heterogeneity in assessment techniques of the biological activity of the L. alba EO used by the scientific community (Ortega-Cuadros \& Tofiño-Rivera, 2019).

It is concluded that $L$. alba EO is a substance of broad spectrum of use, which is why industrial development is feasible based on this raw material. Nevertheless, it is necessary to establish within the SNIA research programs that prioritize the most consistent effects registered in this review, in accordance with national and global demands. Besides, progress is necessary on preliminary tests at pilot scale established by the Colombian norms to advance in the generation of commercial formulations. One of the first steps in this respect corresponds to the methodological harmonization, given that in some studies there was no appropriate control of the variables interfering on the biological quality of the $L$. alba EO, no detailed phyto-chemical analyses were presented, nor were adequate controls involved to facilitate a subsequent meta-analysis that guides the prioritizing of investment resources in the most consistent application lines. Another significant element is the generation of strategic alliances to elaborate protocols to standardize agro-economic management conditions of the plants in production zones, as well as articulation with the industry for scaling of the protocols formulated.

Ethical statement: authors declare that they all agree with this publication and made significant contributions; that there is no conflict of interest of any kind; and that we followed all pertinent ethical and legal procedures and requirements. All financial sources are fully and clearly stated in the acknowledgements section. A signed document has been filed in the journal archives.

\section{ACKNOWLEDGMENTS}

The authors thank the Library at Universidad de Antioquia, the Biblioteca Agropecuaria (BAC) and AGROSAVIA for funding the research "Development of production systems based on aromatic and medicinal species in agro-ecological associations with improved vegetable varieties (hot pepper, bean, and eggplant) for degraded soils of the Caribbean", "Development and validation of sustainable control strategies for parasitic diseases with the greatest productive impact on livestock systems in Colombia". Also, as the project: "Restoration of soils degraded by mining by using rhizo-remediation strategies based on the use of native aromatic species that promote the development of regional micro-economies", of the international mobility call - Argentina 
chapter, 2014 call by COLCIENCIAS. Finally, thanks also go to FONTAGRO, for its project, "Development of regional micro-economies in the production of essential oils harvested in mining soils", from the 2016 call.

\section{RESUMEN}

Actividad biológica de los aceites esenciales del arbusto Lippia alba (Verbenaceae). Introducción: Lippia alba es una especie aromática perteneciente a la familia Verbenaceae, cuyos aceites esenciales han sido empleados en diferentes industrias dada sus propiedades biológicas. Objetivo: identificar las perspectivas de aplicación biotecnológica de los aceites esenciales de Lippia alba. Métodos: se realizó una revisión sistemática exploratoria de la literatura sobre la actividad biológica de aceites esenciales de Lippia alba registrada hasta octubre 2018 en las bases de datos EBSCO, Embase, Pubmed, Scopus, SciELO, y Lilacs. Resultados: los quimiotipos I y III han sido reportados para diferentes actividades biológicas a partir de evaluaciones realizadas en microorganismos, peces, artrópodos, pequeños mamíferos, y líneas celulares; fundamentalmente asociadas con efectos antibacterial, antifúngico, citotóxico, antioxidante y sedante, entre otros. Los registros se enfocaron principalmente a los sectores salud, industria pesquera y agroalimentaria. Conclusión: los estudios sobre el efecto del aceite esencial son promisorios, pero no reflejan una continuidad de la investigación hacia prototipos o productos comerciales acabados. Los grupos de investigación deben unificar metodologías de evaluación e incluir en todos los estudios la relación entre fitoquímica-actividad biológica, para que los metaanálisis sean posibles. De igual manera, deben aunar esfuerzos por medio del Sistema Nacional de Innovación Agropecuaria (SNIA), para generar productos acabados que impacten en la sociedad y faciliten el avance de la bioeconomía del país.

Palabras clave: Lippia alba, aceites esenciales, quimotipos, plantas aromáticas, protección de la salud, industria de alimentos, sector agroalimentario.

\section{REFERENCES}

Agudelo-Gómez, L.S., Gómez, G.A., Durán, D.C., Stashenko, E., \& Betancur-Galvis, L. (2010). Composición química y evaluación de la actividad antiherpética in vitro de aceites esenciales de Lippia alba (Mill) N.E. Brown y sus componentes mayoritarios. Salud UIS, 42(3), 230-239.

Aldana, F., \& Cruz, S. (2017). Larvicidal activity of essential oils of Lippia alba and Lippia graveolens, on Aedes aegypti L. Revista Cientifica, 26(2), 36-48.
Almeida, A.P.G., Heinzmann, B.M., Val, A.L., \& Baldisserotto, B. (2018). Essential oils and eugenol as anesthetics for Serrasalmus rhombeus. Boletim Do Instituto de Pesca, 44(1), 44-50.

Anaruma, N.D., Schmidt, F.L., Duarte, M.C.T., Figueira, G.M., Delarmelina, C., Benato, E.A., ... Sartoratto, A. (2010). Control of Colletotrichum gloeosporioides (penz.) Sacc. In yellow passion fruit using Cymbopogon citratus essential oil. Brazilian Journal of Microbiology, 41(1), 66-73.

Armstrong, R., Hall, B.J., Doyle, J., \& Waters, E. (2011). "Scoping the scope" of a cochrane review. Journal of Public Health, 33(1), 147-150.

Aular, Y., Villamizar, M., Pérez, Y., \& Pérez, V. (2016). Composición química y toxicidad aguda oral del aceite esencial de Lippia alba en ratones. Salus, 20(1), 43-51.

Azambuja, C.R., Mattiazzi, J., Riffel, A.P.K., Finamor, I.A., Garcia, L.O., Heldwein, C.G., ... Llesuy, S.F. (2011). Effect of the essential oil of Lippia alba on oxidative stress parameters in silver catfish (Rhamdia quelen) subjected to transport. Aquaculture, 319(1), 156-161. DOI: https://DOI.org/10.1016/j. aquaculture.2011.06.002.

Baldissera, M.D., Souza, C., Mourão, R.H.V., Silva, L.V.F., \& Monteiro, S.G. (2017). Trypanocidal action of Lippia alba and Lippia origanoides essential oils against Trypanosoma evansi in vitro and in vivo used mice as experimental model. Journal of Parasitic Diseases, 41(2), 345-351. DOI: https://DOI.org/10.1007/ s12639-016-0800-7.

Barrientos, J.C., Reina, M.L., \& Chacón, M.I. (2012). Potencial económico de cuatro especies aromáticas promisorias para producir aceites esenciales en Colombia. Revista Colombiana De Ciencias Hortícolas, 6(2), 225-237.

Batista, E., Brandão, F.R., Majolo, C., Inoue, L.A.K.A., Maciel, P.O., Oliveira, M.R., ... Chagas, E.C. (2018). Lippia alba essential oil as anesthetic for tambaqui. Aquaculture, 495, 545-549. DOI: https://DOI. org/10.1016/j.aquaculture.2018.06.040.

Bersan, S.M.F., Galvão, L.C.C., Goes, V.F.F., Sartoratto, A., Figueira, G.M., Rehder, V.L.G., ... Duarte, M.C.T. (2014). Action of essential oils from Brazilian native and exotic medicinal species on oral biofilms. BMC Complementary and Alternative Medicine, 14(1), 1-12. DOI: https://DOI. org/10.1186/1472-6882-14-451

BIOinTropic, Universidad EAFIT, \& Silo. (2018). Estudio sobre bioeconomía como fuente de nuevas industrias basadas en el capital natural de Colombia. No. 1240667. Fase I: Anexo 4. Revisión de estudios previos y análisis de políticas de la Bioeconomía en Colombia. Universidad EAFIT, Colombia. Retrieved from https://www. 
dnp.gov.co/Crecimiento-Verde/Documents/ejestematicos/Bioeconomia/informe $\% 201 / \mathrm{ANX} 4 . \% 20$ An\%C3\%A1lisis\%20estudios\%20previos\%20y\%20 $\% 20$ pol\%C3\%ADticas $\% 20$ relacionadas.pdf

Blanco, M.A., Colareda, G.A., Baren, C., Bandoni, A.L., Ringuelet, J., \& Consolini, A.E. (2013). Antispasmodic effects and composition of the essential oils from two South American chemotypes of Lippia alba. Journal of Ethnopharmacology, 149(3), 803-809. DOI: https://DOI.org/10.1016/j.jep.2013.08.007.

Bouyahya, A., Guaouguaou, F.E., Dakka, N., \& Bakri, Y. (2017). Pharmacological activities and medicinal properties of endemic Moroccan medicinal plant Origanum compactum (Benth) and their main compounds. Asian Pacific Journal of Tropical Disease, 7(10), 628-640. DOI: https://DOI.org/10.12980/ apjtd.7.2017D7-31.

Caballero-Gallardo, K., Olivero-Verbel, J., \& Stashenko, E.E. (2011). Repellent activity of essential oils and some of their individual constituents against Tribolium castaneum herbst. Journal of Agricultural and Food Chemistry, 59(5), 1690-1696. DOI: https:// DOI.org/10.1021/jf103937p

Cárdenas, C., Toni, C., Martos-Sitcha, J.A., Cárdenas, S., Heras, V., Baldisserotto, B., ... Mancera, J.M. (2016). Effects of clove oil, essential oil of Lippia alba and 2-phe anaesthesia on juvenile meagre, Argyrosomus regius (Asso, 1801). Journal of Applied Ichthyology, 32(4), 693-700. DOI: https://DOI.org/10.1111/ jai. 13048

Carvalho, P.M., Macêdo, C.A.F., Ribeiro, T.F., Silva, A.A., Silva, R.E.R., Morais, L.P., ... Barbosa, R. (2018). Effect of the Lippia alba (Mill.) N.E. Brown essential oil and its main constituents, citral and limonene, on the tracheal smooth muscle of rats. Biotechnology Reports, 17, 31-34. DOI: https://DOI.org/10.1016/j. btre.2017.12.002

Castillo, R.M., Stashenko, E., \& Duque, J.E. (2017). Insecticidal and Repellent Activity of Several Plant-Derived Essential Oils Against Aedes aegypti. Journal of the American Mosquito Control Association, 33(1), 25-35. DOI: https://DOI.org/10.2987/16-6585.1

Chagas, A.C.S., Oliveira, M.C.S., Giglioti, R., Santana, R.C.M., Bizzo, H.R., Gama, P.E., \& Chaves, F.C.M. (2016). Efficacy of 11 Brazilian essential oils on lethality of the cattle tick Rhipicephalus (Boophilus) microplus. Ticks and Tick-Borne Diseases, 7(3), 427-432. DOI: https://DOI.org/10.1016/j. ttbdis.2016.01.001

Costa, D.C.M., Vermelho, A.B., Almeida, C.M., Dias, E.P.S., Cedrola, S.M.L., Arrigoni-Blank, M. F., ... Alviano, D.S. (2014). Inhibitory effect of linaloolrich essential oil from Lippia alba on the peptidase and keratinase activities of dermatophytes. Journal of Enzyme Inhibition and Medicinal Chemistry, 29(1),
12-17. DOI: https://DOI.org/10.3109/14756366.20 12.743537

Cunha, M.A., Barros, F.M.C., Garcia, L.O., Veeck, A.P.L., Heinzmann, B.M., Loro, V.L., ... Baldisserotto, B. (2010). Essential oil of Lippia alba: A new anesthetic for silver catfish, Rhamdia quelen. Aquaculture, 306, 403-406. DOI: https://DOI.org/10.1016/j. aquaculture.2010.06.014

Cunha, M.A., Silva, B.F., Delunardo, F.A.C., Benovit, S.C., Gomes, L.C., Heinzmann, B.M., \& Baldisserotto, B. (2011). Anesthetic induction and recovery of Hippocampus reidi exposed to the essential oil of Lippia alba. Neotropical Ichthyology, 9(3), 683-688. DOI: https://DOI.org/10.1590/S1679-62252011000300022

Célis, M. (2018). El último metaanálisis sobre antidepresivos: Nada nuevo bajo el sol. Clínica Contemporánea, 9(1), 1-5. DOI: https://DOI.org/10.5093/cc2018a7

Delgado, J., Sánchez, M.S., \& Bonilla, C.R. (2016). Efecto del secado y la edad de las plantas en la composición de los aceites esenciales de Lippia alba (Mill.) N.E.Br. ex Britton \& amp; P. Wilson y Lippia origanoides Kunth. Acta Agronómica, 65(2), 170-175. DOI: https://DOI.org/10.15446/acag.v65n2.47576

Duarte, M.C.T., Figueira, G.M., Sartoratto, A., Rehder, V.L., \& Delarmelina, C. (2005). Anti-Candida Activity of Brazilian Medicinal plants. Journal of Ethnopharmacology, 97(2), 305-311. DOI: https://DOI. org/10.1016/j.jep.2004.11.016

Duarte, M.C.T., Leme, E.E., Delarmelina, C., Soares, A.A., Figueira, G.M., \& Sartoratto, A. (2007). Activity of essential oils from Brazilian medicinal plants on Escherichia coli. Journal of Ethnopharmacology, 111(2), 197-201. DOI: https://DOI.org/10.1016/j. jep.2006.11.034

Durán, D.C., Monsalve, L.A., Martínez, J.R., \& Stashenko, E.E. (2007). Estudio comparativo de la composición química de aceites esenciales de Lippia alba provenientes de diferentes regiones de Colombia, y efecto del tiempo de destilación sobre la composición del aceite. Scientia et Technica, 1(33), 435-438.

Escobar, P., Leal, S.M., Herrera, L.V., Martinez, J.R., \& Stashenko, E. (2010). Chemical composition and antiprotozoal activities of Colombian Lippia spp essential oils and their major components. Memórias do Instituto Oswaldo Cruz, 105(2), 184-190. DOI: https://DOI.org/10.1590/S0074-02762010000200013

Fauth, S., Campos, A.R., Silveira, E.R., \& Rao, V.S. (2002). Efeitos de óleos essenciais de plantas no tempo de sono induzido por cetamina em camundongos. Revista Brasileira de Farmacognosia, 12, 112-113. DOI: https://DOI.org/10.1590/ S0102-695X2002000300052

García-Perdomo, H.A. (2015). Conceptos fundamentales de las revisiones sistemáticas/metaanálisis. 
Urología Colombiana, 24(1), 28-34. DOI: https:// DOI.org/10.1016/j.uroco.2015.03.005

Glamočlija, J., Soković, M., Tešević, V., Linde, G.A., \& Colauto, N.B. (2011). Chemical characterization of Lippia alba essential oil: an alternative to control green molds. Brazilian Journal of Microbiology, 42(4), 1537-1546. DOI: https://DOI.org/10.1590/ S1517-838220110004000041

Gomide, M., Lemos, F., Lopes, M., Alves, T., Viccini, L., \& Coelho, C. (2013). The effect of the essential oils from five different Lippia species on the viability of tumor cell lines. Revista Brasileira de Farmacognosia, 23(2013), 895-902. DOI: https://DOI. org/10.1590/S0102-695X2013000600006

Grand View Research. (2018). Market Research Report (Data base). Retrieved from https://bit.ly/2S1bL8T

Hatano, V.Y., Torricelli, A.S., Giassi, A.C.C., Coslope, L.A., \& Viana, M.B. (2012). Anxiolytic effects of repeated treatment with an essential oil from Lippia alba and (R)-(-)-carvone in the elevated T-maze. Brazilian Journal of Medical and Biological Research, 45(3), 238-243. DOI: https://DOI.org/10.1590/ S0100-879X2012007500021

Hohlenwerger, J.C., Baldisserotto, B., Couto, R.D., Heinzmann, B.M., Silva, D.T., Caron, B.O., ... Copatti, C. E. (2017). Essential oil of Lippia alba in the transport of Nile tilapia | Óleo essencial de Lippia alba no transporte de tilápia-do-Nilo. Ciencia Rural, 47(3), 1-4. DOI: https://DOI.org/10.1590/0103-8478cr20160040

Instituto Colombiano de Normas Técnicas y Certificación (ICONTEC). (2011). Guía sobre pruebas de estabilidad, cosméticos y productos de higiene doméstica (Guía técnica colombiana GTC 215). Colombia: ICONTEC. Retrieved from https://tienda.icontec.org/ wp-content/uploads/pdfs/GTC215.pdf

Instituto Nacional de Vigilancia de Medicamentos y Alimentos (INVIMA). Por el cual se reglamenta parcialmente el Régimen de Registros y Licencias, el Control de Calidad, así como el Régimen de Vigilancia Sanitaria de Medicamentos, Cosméticos, Preparaciones Farmacéuticas a base de Recursos Naturales, Productos de Aseo, Higiene y Limpieza $y$ otros productos de uso doméstico y se dictan otras disposiciones sobre la materia. (Decreto 677 de 1995). Colombia, INVIMA Retrieved from https:// www.invima.gov.co/documents/20143/453029/ decreto_677_1995.pdf

Instituto Nacional de Vigilancia de Medicamentos y Alimentos (INVIMA). (2018). Listado de plantas medicinales aceptadas con fines terapéuticos. Colombia: INVIMA Retrieved from https://bit.ly/2HmGxb0

Juiz, P.J.L., Lucchese, A.M., Gambari, R., Piva, R., Penolazzi, L., Ciano, M., ... Avila-Campos, M. J. (2015). Essential oils and isolated compounds from Lippia alba leaves and flowers: Antimicrobial activity and osteoclast apoptosis. International Journal of Molecular Medicine, 35(1), 211-217. DOI: https://DOI. org/10.3892/ijmm.2014.1995

Junior, G.B., Abreu, M.S., Rosa, J.G.S., Pinheiro, C.G., Heinzmann, B.M., Caron, B.O., ... Barcellos, L.J.G. (2018). Lippia alba and Aloysia triphylla essential oils are anxiolytic without inducing aversiveness in fish. Aquaculture, 482(2018), 49-56. DOI: https:// DOI.org/10.1016/j.aquaculture.2017.09.023

Lima, A.S., Carvalho, J.F., Peixoto, M.G., Blank, A.F., Borges, L.M.F.F., \& Junior, L.M. (2016). Assessment of the repellent effect of Lippia alba essential oil and major monoterpenes on the cattle tick Rhipicephalus microplus. Medical and Veterinary Entomology, 30(1), 73-77. DOI: https://DOI.org/10.1111/ mve. 12140

Linde, G.A., Colauto, N.B., Albertó, E., \& Gazim, Z.C. (2016). Quimiotipos, Extracción, Composición y Aplicaciones del Aceite Esencial de Lippia alba. Revista Brasileira de Plantas Medicinais, 18(1), 191-200. DOI: https://DOI.org/10.1590/1983-084X/15_037

López, M.A., Stashenko, E.E., \& Fuentes, J.L. (2011). Chemical composition and antigenotoxic properties of Lippia alba essential oils. Genetics and Molecular Biology, 34(3), 479-488. DOI: https://DOI. org/10.1590/S1415-47572011005000030

Machado, T.F., Nogueira, N.A., Pereira, R.C.A., Sousa, C.T., \& Batista, V.C. (2014). The antimicrobial efficacy of Lippia alba essential oil and its interaction with food ingredients. Brazilian Journal of Microbiology, 45(2), 699-705. DOI: https://DOI.org/10.1590/ S1517-83822014000200045

Majolo, C., Rocha, S.I.B., Chagas, E.C., Chaves, F.C.M., \& Bizzo, H.R. (2017). Chemical composition of Lippia spp. essential oil and antimicrobial activity against Aeromonas hydrophila. Aquaculture Research, 48(5), 1-8. DOI: https://DOI.org/10.1111/are.13073

Maynard, L.G., Santos, K.C., Cunha, P.S., Barreto, A.S., Peixoto, M.G., Arrigoni-Blank, F., ... Santos. M.R. (2011). Chemical composition and vasorelaxant effect induced by the essential oil of Lippia alba (Mill.) N.E. Brown. (Verbenaceae) in rat mesenteric artery. Indian Journal of Pharmacology, 43(6), 694698. DOI: https://DOI.org/10.4103/0253-7613.89828

Mena-Rodríguez, E., Ortega-Cuadros, M., Merini, L., Melo-Ríos, A.E., \& Tofiño-Rivera, A.P. (2018). Efecto de agroinsumos y aceites esenciales en el suelo de hortalizas en el Caribe colombiano. Corpoica Ciencia y Tecnología Agropecuaria, 19(1), 103-124. DOI: https://DOI.org/10.21930/rcta.vol19_num1_art:535

Meneses, R., Ocazionez, R., Martínez, J., \& Stashenko, E. (2009). Inhibitory effect of essential oils obtained from plants grown in Colombia on yellow fever virus replication in vitro. Annals of Clinical Microbiology 
and Antimicrobials, 8(8), 1-6. DOI: https://DOI. org/10.1186/1476-0711-8-8

Mesa-Arango, A.C., Montiel-Ramos, J., Zapata, B., Durán, C., Betancur-Galvis, L., \& Stashenko, E. (2009). Citral and carvone chemotypes from the essential oils of Colombian Lippia alba (Mill.) N.E. Brown: composition, cytotoxicity and antifungal activity. Memorias Do Instituto Oswaldo Cruz, 104(6), 878-884. DOI: https://DOI.org/10.1590/S0074-02762009000600010

Mesa-Arango, A.C., Betancur-Galvis, L., Montiel, J., Bueno, J.G., Baena, A., Durán, D.C., ... Stashenko, E.E. (2010). Antifungal activity and chemical composition of the essential oils of Lippia alba (miller) N.E Brown grown in different regions of Colombia. Journal of Essential Oil Research, 22(6), 568-574. DOI: https://DOI.org/10.1080/10412905.2010.9700402

Ministerio de Salud y Protección Social (MinSalud). (2003). Por el cual se modifica el artículo $13 \mathrm{del}$ Decreto 677 de 1995 y se dictan otras disposiciones (Decreto 2510 de 2003). MinSalud: Colombia. Retrieved from https://www.icbf.gov.co/cargues/ avance/docs/decreto_2510_2003.htm

Ministerio de Salud y Protección Social (MinSalud). (2008). Vademécum Colombiano de Plantas Medicinales. Colombia: MinSalud. Retrieved from https:// bit.ly/2UGvNXD

Moreira, F.J.C., Santos, C.D.G., \& Innecco, R. (2009). Hatching and mortality of second-stage juveniles of Meloidogyne incognita race 2 in essential plant oils. Revista Ciencia Agronomica, 40(3), 441-448.

Moreno, É.M., Leal, S.M., Stashenko, E.E., \& García, L.T. (2018). Induction of programmed cell death in Trypanosoma cruzi by Lippia alba essential oils and their major and synergistic terpenes (citral, limonene and caryophyllene oxide). BMC Complementary and Alternative Medicine, 18(1), 225. DOI: https://DOI. org/10.1186/s12906-018-2293-7

Muñoz, J.A., Staschenko, E., \& Ocampo, C.B. (2014). Actividad insecticida de aceites esenciales de plantas nativas contra Aedes aegypti (Diptera: Culicidae). Revista Colombiana de Entomología, 40(2), 198-202. DOI: https://DOI.org/ISSN 0120-0488

Neira, L.F., Mantilla, J.C., Stashenko, E., \& Escobar, P. (2018). Toxicidad, genotoxicidad y actividad antiLeishmania de aceites esenciales obtenidos de cuatro (4) quimiotipos del género Lippia. Boletín Latinoamericano y del Caribe de Plantas Medicinales y Aromáticas, 17(1), 68-83.

Ocazionez, R.E., Meneses, R., Torres, F.Á., \& Stashenko, E. (2010). Virucidal activity of Colombian Lippia essential oils on dengue virus replication in vitro. Memorias Do Instituto Oswaldo Cruz, 105(3), 304-309. DOI: https://DOI.org/10.1590/S0074-02762010000300010
Olivero-Verbel, J., Güette-Fernandez, J., \& Stashenko, E. (2009). Acute toxicity against Artemia franciscana of essential oils isolated from plants of the genus Lippia and Piper collected in Colombia. Boletín Latinoamericano y del Caribe de Plantas Medicinales y Aromáticas, 8(5), 419-427.

Olivero-Verbel, J., González-Cervera, T., Güette-Fernandez, J., Jaramillo-Colorado, B., \& Stashenko, E. (2010). Chemical composition and antioxidant activity of essential oils isolated from Colombian plants. Brazilian Journal of Pharmacognosy, 20(4), 568-574. DOI: https://DOI.org/10.1590/ S0102-695X2010000400016

Olivero-Verbel, J., Guerrero-Castilla, A., \& Stashenko, E. (2010). Toxicity of the essential oil of the cytral chemotype of Lippia alba (Mill.) N. E. Brown. Acta Toxicológica Argentina, 18(1), 21-27.

Ortega-Cuadros, M., Tofiño-Rivera, A.P., Merini, L.J., \& Martinez-Pabón, M.C. (2018). Antimicrobial activity of Cymbopogon citratus (Poaceae) essential oil on Streptococcus mutans biofilm and cytotoxic effect on keratinocytes and fibroblasts. Revista de Biología Tropical, 66(4), 1519-1529. DOI: https://DOI. org/10.15517/rbt.v66i4.33140

Ortega-Cuadros, M. \& Tofiño-Rivera, A.P. (2019). Revisión exploratoria de la actividad antibacteriana y antifúngica de Lippia alba (Mill.) N. E. Br (pronto alivio). Revista Cubana de Plantas Medicinales, 24(1), 1-14.

Palacio-López, K., \& Rodríguez-López, N. (2008). Plasticidad fenotípica en Lippia alba (Verbenaceae) en respuesta a la disponibilidad hídrica en dos ambientes lumínicos. Acta Biológica Colombiana, 13(1), 187-198.

Parodi, T.V., Cunha, M.A., Heldwein, C.G., Souza, D.M., Martins, A.C., Garcia, L., ... Baldisserotto, B. (2012). The anesthetic efficacy of eugenol and the essential oils of Lippia alba and Aloysia triphylla in post-larvae and sub-adults of Litopenaeus vannamei (Crustacea, Penaeidae). Comparative Biochemistry and Physiology, 155(3), 462-468. DOI: https://DOI. org/10.1016/j.cbpc.2011.12.003

Peixoto, M.G., Bacci, L., Fitzgerald Blank, A., Araújo, A.P.A., Alves, P.B., Silva, J.H.S., ... Arrigoni-Blank, M. (2015a). Toxicity and repellency of essential oils of Lippia alba chemotypes and their major monoterpenes against stored grain insects. Industrial Crops and Products, 71(2015), 31-36. DOI: https://DOI. org/10.1016/j.indcrop.2015.03.084

Peixoto, M.G., Costa-Júnior, L.M., Blank, A.F., Lima, A., Menezes, T.S.A., Santos, D., ... Arrigoni-Blank, M. (2015b). Acaricidal activity of essential oils from Lippia alba genotypes and its major components carvone, limonene, and citral against Rhipicephalus microplus. Veterinary Parasitology, 210, 118-122. DOI: https://DOI.org/10.1016/j.vetpar.2015.03.010 
Pino, J.A., Ortega, L.A., Rosado, A. Rodríguez, M., \& Baluja, R. (1996). Composición y propiedades antibacterianas del aceite esencial de Lippia alba (Mill.) N.E. Brown. Revista Cubana de Farmacia, 30(1), 29-35.

Plantlife International. (2004). Herbal harvests with a future. Towards sustainable sources for medicinal plants. Retrieved from https://goo.gl/N66iRp

Porfírio, E.M., Melo, H.M., Pereira, A.M.G., Cavalcante, T.T.A., Gomes, G.A., Carvalho, M.G., ... Júnior, F.E.A.C. (2017). In Vitro Antibacterial and Antibiofilm Activity of Lippia alba Essential Oil, Citral, and Carvone against Staphylococcus aureus. Scientific World Journal, 2017, 1-7. DOI: https://DOI. org $/ 10.1155 / 2017 / 4962707$

Ramírez, L., \& Castaño, D. (2009). Metodologías para evaluar in vitro la actividad antibacteriana de compuestos de origen vegetal. Scientia et Technica, 15(42), 263-268

Ríos, N., Stashenko, E.E., \& Duque, J.E. (2017). Evaluation of the insecticidal activity of essential oils and their mixtures against Aedes aegypti (Diptera: Culicidae). Revista Brasileira de Entomologia, 61(4), 307311. DOI: https://DOI.org/10.1016/j.rbe.2017.08.005

Rodrigues-Soares, J.P., Jesus, G.F.A., Gonçalves, E.L.T., Moraes, K.N., Chagas, E.C., Chaves, F. C.M., .. Martins, M.L. (2018). Induced aerocystitis and hemato-immunological parameters in nile tilapia fed supplemented diet with essential oil of Lippia alba. Brazilian Journal of Veterinary Research and Animal Science, 55(1), 1-12. DOI: https://DOI.org/10.11606/ issn.1678-4456.bjvras.2018.136717

Salbego, J., Becker, A., Gonçalves, J., Menezes, C., Heldwein, C., Spanevello, R., ... Baldisserotto, B. (2014). The essential oil from Lippia alba induces biochemical stress in the silver catfish (Rhamdia quelen) after transportation. Neotropical Ichthyology, 12(4), 811-818. DOI: https://DOI. org/10.1590/1982-0224-20130178

Salbego, J., Maia, J.L., Toni, C., Rodrigues, A.S.S., Sousa, E.M.O., Silva, L.V.F., ... Baldisserotto, B. (2017a). Anesthesia and sedation of map treefrog (Hypsiboas geographicus) tadpoles with essential oils. Ciência Rural, 47(11), 1-6.

Salbego, J, Toni, C., Becker, A.G., Zeppenfeld, C.C., Menezes, C.C., Loro, V.L., ... Baldisserotto, B. (2017b). Biochemical parameters of silver catfish (Rhamdia quelen) after transport with eugenol or essential oil of Lippia alba added to the water. Brazilian Journal of Biology, 77(4), 696-702. https://DOI org/10.1590/1519-6984.16515

Santos, N., Pascon, R., Vallim, M., Figueiredo, C., Soares, M., Lago, J.H., \& Sartorelli, P. (2016a). Cytotoxic and Antimicrobial Constituents from the Essential Oil of Lippia alba (Verbenaceae). Medicines, 3(3), 2-9. DOI: https://DOI.org/10.3390/medicines3030022

Santos, I.G., Scher, R., Rott, M.B., Menezes, L.R., Costa, E.V., Cavalcanti, S.C., ... Dolabella, S. (2016b). Amebicidal activity of the essential oils of Lippia spp. (Verbenaceae) against Acanthamoeba polyphaga trophozoites. Parasitology Research, 115(2), 535-540. DOI: https://DOI.org/10.1007/s00436-015-4769-4

Sena, A.C., Teixeira, R.R., Ferreira, E.L., Heinzmann, B.M., Baldisserotto, B., Caron, B.O., ... Copatti, C.E. (2016). Essential oil from Lippia alba has anaesthetic activity and is effective in reducing handling and transport stress in tambacu (Piaractus mesopotamicus $\times$ Colossoma macropomum). Aquaculture, 465(2016), 374-379. DOI: https://DOI.org/10.1016/j. aquaculture.2016.09.033

Sepúlveda-Arias, J.C., Veloza, L.A., Escobar, L.M., Orozco, L.M., \& Lopera, I.A. (2013). Anti-inflammatory effects of the main constituents and epoxides derived from the essential oils obtained from Tagetes lucida, Cymbopogon citratus, Lippia alba and Eucalyptus citriodora. Journal of Essential Oil Research, 25(3), 186-193. DOI: https://DOI.org/10.1080/10412905.2 012.751556

Shukla, R., Kumar, A., Singh, P., \& Dubey, N. K. (2009). Efficacy of Lippia alba (Mill.) N.E. Brown essential oil and its monoterpene aldehyde constituents against fungi isolated from some edible legume seeds and aflatoxin B1 production. International Journal of Food Microbiology, 135(2), 165-170. DOI: https:// DOI.org/10.1016/j.ijfoodmicro.2009.08.002

Simões, L.N., Medeiros, L.C.C., Heinzmann, B.M., Loro, V.L., Gomes, L.C., Silva, D.T., ... Baldisserotto, B. (2017). Essential oil of Lippia alba as a sedative and anesthetic for the sea urchin Echinometra lucunter (Linnaeus, 1758). Marine and Freshwater Behaviour and Physiology, 50(3), 205-217. DOI: https://DOI. org/10.1080/10236244.2017.1362317

Silva, R.E.R., Morais, L.P., Silva, A.A., Bastos, C.M.S., Pereira-Gonçalves, Á., Kerntopf, M.R., ... Barbosa, R. (2018). Vasorelaxant effect of the Lippia alba essential oil and its major constituent, citral, on the contractility of isolated rat aorta. Biomedicine and Pharmacotherapy, 108, 792-798. DOI: https://DOI. org/10.1016/j.biopha.2018.09.073

Soares, B.V., Neves, L.R., Oliveira, M.S.B., Chaves, F.C.M., Dias, M.K.R., Chagas, E.C., \& TavaresDias, M. (2016). Antiparasitic activity of the essential oil of Lippia alba on ectoparasites of Colossoma macropomum (tambaqui) and its physiological and histopathological effects. Aquaculture, 452(2016), 107-114. DOI: https://DOI.org/10.1016/j. aquaculture.2015.10.029

Sousa, D.G., Sousa, S.D.G., Silva, R.E.R., Silva-Alves, K.S., Ferreira-da-Silva, F.W., Kerntopf, M.R., ... Barbosa, R. (2015). Essential oil of Lippia alba and 
its main constituent citral block the excitability of rat sciatic nerves. Brazilian Journal of Medical and Biological Research, 48(8), 697-702. DOI: https:// DOI.org/10.1590/1414-431X20154710

Souza, P.M., Goulart, F.R.G., Marques, J.M., Bizzo, H.R., Blank, A.F., Groposo, C., ... Seldin, L. (2017a). Growth Inhibition of Sulfate-Reducing Bacteria in Produced Water from the Petroleum Industry Using Essential Oils. Molecules, 22(4), 1-10. https://DOI. org/10.3390/molecules 22040648

Souza, R.C., Costa, M.M., Baldisserotto, B., Heinzmann, B.M., Schmidt, D., Caron, B.O., \& Copatti, C.E. (2017b). Antimicrobial and synergistic activity of essential oils of Aloysia triphylla and Lippia alba against Aeromonas spp. Microbial Pathogenesis, 113(2017), 29-33. https://DOI.org/10.1016/j. micpath.2017.10.013

Souza, C., Lima, T., Baldissera, M., Geihs, M., Maciel, F., Nery, L., ... Baldisserotto, B. (2018). Nanoencapsulated Melaleuca alternifolia essential oil exerts anesthetic effects in the brachyuran crab using Neohelice granulate. Anais Da Academia Brasileira de Ciencias, 90(3), 2855-2864. DOI: https://DOI. org/10.1590/0001-3765201820170930

Stashenko, E.E., Jaramillo, B.E., \& Martínez, J.R. (2004). Comparison of different extraction methods for the analysis of volatile secondary metabolites of Lippia alba (Mill.) N.E. Brown, grown in Colombia, and evaluation of its in vitro antioxidant activity. Journal of Chromatography A, 1025(1), 93-103. DOI: https:// DOI.org/10.1016/j.chroma.2003.10.058

Sutili, F., Cunha, M., Ziech, R., Krewer, C., Zeppenfeld, C., Heldwein, C., ... Baldisserotto, B. (2015). Lippia alba essential oil promotes survival of silver catfish (Rhamdia quelen) infected with Aeromonas sp. Anais Da Academia Brasileira de Ciências, 87(1), 95-100. DOI: https://DOI.org/10.1590/0001-3765201520130442

Tangarife-Castaño, V., Roa-Linares, V., Betancur-Galvis, L.A., Durán García, D.C., Stashenko, E., \& Mesa-Arango, A.C. (2012). Antifungal activity of Verbenaceae and Labiatae families essential oils. Pharmacologyonline, 1, 133-145.

Tofiño-Rivera, A.P., Ortega-Cuadros, M., Galvis-Pareja, D., Jimenez-Rios, H., Merini, L.J., \& MartinezPabón, M.C. (2016). Effect of Lippia alba and Cymbopogon citratus essential oils on biofilms of Streptococcus mutans and cytotoxicity in CHO cells. Journal of Ethnopharmacology, 194(2016), 749-754. DOI: https://DOI.org/10.1016/j.jep.2016.10.044

Tofiño-Rivera, A.P., Ortega-Cuadros, M., Melo-Ríos, A., \& Mier-giraldo, H.J. (2017). Vigilancia tecnológica de plantas aromáticas: de la investigación a la consolidación de la agrocadena colombiana. Corpoica Ciencia y Tecnología Agropecuaria, 18(2), 1-25. DOI: https:// DOI.org/10.21930/rcta.vol18_num2_art:636

Toni, C., Becker, A.G., Simões, L.N., Pinheiro, C.G., Silva, L., Heinzmann, B.M., ... Baldisserotto, B. (2014). Fish anesthesia: Effects of the essential oils of Hesperozygis ringens and Lippia alba on the biochemistry and physiology of silver catfish (Rhamdia quelen). Fish Physiology and Biochemistry, 40(3), 701-714. DOI: https://DOI.org/10.1007/s10695-013-9877-4

Toni, C., Martos-Sitcha, J.A., Baldisserotto, B., Heinzmann, B.M., Silva, L., Martínez-Rodríguez, G., \& Mancera, J.M. (2015). Sedative effect of 2-phenoxyethanol and essential oil of Lippia alba on stress response in gilthead sea bream (Sparus aurata). Research in Veterinary Science, 103, 20-27. DOI: https://DOI.org/10.1016/j.rvsc.2015.09.006

Valero, M.A., Vidal, A., Burgos, R., Calvo, F.L., Martínez, C., Luengo, L.M., \& Cuerda, C. (2011). Meta-análisis del papel del licopeno en la diabetes mellitus tipo 2. Nutrición Hospitalaria, 26(6), 1236-1241. DOI: https://DOI.org/10.3305/nh.2011.26.6.5406

Veeck, A. P., Klein, B., Ferreira, L., Becker, A., Heldwein, C., Heinzmann, B., ... Emanuelli, T. (2013). Lipid stability during the frozen storage of fillets from silver catfish exposed in vivo to the essential oil of Lippia alba (Mill.) NE Brown. Journal of the Science of Food and Agriculture, 93(4), 955-960. DOI: https:// DOI.org/10.1002/jsfa.5833

Veeck, A.P.L., Daniel, A.P., Klein, B., Quatrin, A., Rezer, A.P.S., Milani, L.G., ... Emanuelli, T. (2018). Chemical, microbiological, and sensory parameters during the refrigerated storage of silver catfish (Rhamdia quelen) exposed in vivo to the essential oil of Lippia alba. Journal of Food Science and Technology, 55(4), 1416-1425. DOI: https://DOI.org/10.1007/ s13197-018-3056-7

Veit, J., Piccolo, J., Scherer, A., Machado, I., Peres, M., Schwerz, J., ... Emanuelli, T. (2017). Stability of frozen fillets from silver catfish anesthetized with essential oil of Lippia alba prior to electrical stunning or hypothermia. Journal of Food Processing and Preservation, 41(5), 1-10. DOI: https://DOI.org/10.1111/ jfpp. 13167

Vera, A.P., Olivero, J., Jaramillo, B., \& Stashenko, E. (2010). Efecto protector del aceite esencial de Lippia alba (Mill.) N.E.: Brown sobre la toxicidad del mercurocromo en raíces de Allium cepa L. Revista Cubana de Plantas Medicinales, 15(1), 27-37.

Vera, S.S., Zambrano, D.F., Méndez-Sanchez, S.C., Rodríguez-Sanabria, F., Stashenko, E.E., \& Luna, J.E. (2014). Essential oils with insecticidal activity against larvae of Aedes aegypti (Diptera: Culicidae). Parasitology Research, 113(7), 2647-2654. DOI: https://DOI.org/10.1007/s00436-014-3917-6 
Viana, G.S., Vale, T.G., Silva, C.M.M., \& Matos, F.J. (2000). Anticonvulsant activity of essential oils and active principles from chemotypes of Lippia alba (Mill.) N.E. Brown. Biological and Pharmaceutical Bulletin, 23(11), 1314-1317. DOI: https://DOI. org/10.1248/cpb.37.3229

World Health Organization (WHO). (2004). New WHO guidelines to promote proper use of alternative medicines. Geneva: World Health Organization. Retrieved from https://www.who.int/mediacentre/news/ releases/2004/pr44/en
Zambrano, É.L., Buitrago, L.Á., Durán, L., Sánchez, M.S., \& Bonilla, C.R. (2013). Efecto de la fertilización nitrogenada en el rendimiento y la composición de los aceites esenciales de especies y accesiones de Lippia. Acta Agronómica, 62(2), 129-135.

Zapata, B., Betancur-Galvis, L., Duran, C., \& Stashenko, E. (2013). Cytotoxic activity of Asteraceae and Verbenaceae family essential oils. Journal of Essential Oil Research, 26(1), 50-57. DOI: https://DOI.org/10. 1080/10412905.2013.820674 